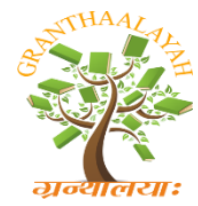

INTERNATIONAL JOURNAL OF RESEARCH GRANTHAALAYAH A knowledge Repository

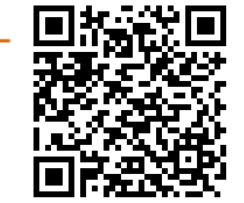

Social

\title{
SOCIAL INTELLIGENCE AND ACHIEVEMENT IN SCIENCE AMONG HIGHER SECONDARY SCHOOL STUDENTS
}

\author{
Dr. D. Vinodhkumar ${ }^{* 1}$, R. Pankajam ${ }^{2}$ \\ ${ }^{*}$ Assistant Professor \& Research Supervisor, Department of Education, Tamilnadu Open \\ University, Chennai, India \\ ${ }^{2}$ Ph.D. Research Scholar, Dravidian University, Kuppam, A.P., India \\ DOI: https://doi.org/10.29121/granthaalayah.v5.i1(SE).2017.1915
}

\begin{abstract}
The present study intended to find out the level of Social Intelligence and Achievement in Science among Higher Secondary School Students. This study belongs to Survey Method. The size of the sample in the study was 300 Higher Secondary School Students who were selected through Random Sampling Technique. The investigators had used Social Intelligence Scale developed by Baskaran. P and Anandan. K (2011) and Achievement Test in Science (ATS) developed by the Investigators. The Statistical techniques used in this study were Mean, Standard deviation, $t$ ' test and Correlation to analyse the data. It was inferred that there is significant relationship between Social Intelligence and Achievement in science among selected High School Students.
\end{abstract}

Keywords: Social Intelligence; Achievement; Higher Secondary School \& Environments.

Cite This Article: Dr. D.Vinodhkumar, and R. Pankajam. (2017). "SOCIAL INTELLIGENCE AND ACHIEVEMENT IN SCIENCE AMONG HIGHER SECONDARY SCHOOL STUDENTS.” International Journal of Research - Granthaalayah, 5(1)SE, 9-13. https://doi.org/10.29121/granthaalayah.v5.i1(SE).2017.1915.

\section{Introduction}

Social intelligence is the ability to effectively navigate and negotiate complex social relationships and environments. It is perceived that the social intelligence may influence the academic achievement of the students. Social scientist Ross Honey (1985) believes social intelligence is an aggregated measure of self- and social-awareness, evolved social beliefs and attitudes, and a capacity and appetite to manage complex social change. The definition for Social Intelligence was given by Edward Thorndike (1920) is "the ability to understand and manage men and women, boys and girls, to act wisely in human relations". It is similar to interpersonal intelligence, one of the types of intelligence identified in Howard Gardner's theory of multiple 
intelligences, and closely related to theory of mind. The investigators are interested to know to what extent social intelligence contribute towards the academic achievement that too in science.

\section{Review of the Related Literature}

Chandra (2013) conducted a study on "Achievement in Science through Rastriya Madhyamik Shiksha Abiyan among the Students of Standard IX". The study belongs to Survey research. The study carry out 195 Students have been selected by random sampling from the schools. The major findings of the study were: 1) The Female Students are having significantly higher level of Achievements in Science through Rastriya Madhyamik Shiksha Abiyan than the Male Students. 2) Urban Students are having significantly higher level of Achievements in Science through Rastriya Madhyamik Shiksha Abiyan than the Rural Students. 3). Aided School Students are having significantly higher level of Achievements in Science through Rastriya Madhyamik Shiksha Abiyan than the Government School Students.

Edwin Thangom (2012) made an "A study on the Effective of Using Science Lab Equipment on the Achievement in Science among the Students of Standard IX". The study belongs to Experimental Research. The sample consisted of 57 Students. Achievement Test in Science as tool for this study. The major findings of the study were: 1) The Female students secured significantly higher achievement score in science than the male students. 2) The SC students secured significantly higher achievement score in science than the BC and MBC students. 3). The Mean achievement scores in science were found to be high.

Gopal, Mirunalini \& Anandan (2012) made a study on Gender and Parental Income towards the Effectiveness of Computer Assisted Instruction on Achievement in Science among Primary School Students. The aim of the present study is to measure the Gender and Parental Income towards the Effectiveness of Computer Assisted Instruction on Achievement in Science among Primary School Students. The Study belongs to Experimental Research. Single group sampling design was followed in the study. The size of the sample is Forty Two students studying in primary school were selected through Random Sampling Technique. The investigators themselves developed the tool 'Achievement in Science' which consists of forty items comprising three units in multiple choice pattern. Standardised CAI Software on selected science concepts were used as treatment. Mean, Standard deviation and ' $t$ ' test techniques were used for analyzing the data. The findings revealed that the Gender and Parental Income towards the Effectiveness of Computer Assisted Instruction on Achievement in Science among Primary School Students.

It also revealed that there is no significant difference on Gain Scores of the Mean Achievements in Science through the treatment of CAI software among Primary school students with respect to Gender and Parental Income

Ruey Shieh, Wheijen Chang \& Eric Zhi-Fengliv (2011) conducted a study on Technology Enabled Active Learning (TEAL) in Introductory Physics: Impact on Gender and Achievement Levels. This study explored the impact of technology enabled active learning (TEAL) on students learning general Physics, focusing on differences between genders and among various achievement levels. A quasi-experimental investigation was conducted in this study. Data 
sources consisted of Pre-tests, Post-tests, self- Report Surveys, Class Observation and Interview data. The statistical Techniques used in this study were Mean, standard Deviation and ' $t$ ' test .The findings of this study indicate that the learning gain achieved by the experimental group was $11 \%$ higher than that achieved by the control group in the first semester, though the margin decreased to $1 \%$ in the second semester. In the situation of the low achievement level, there was no significant difference found in the learning gain achieved by the two groups in the second semester. The qualitative data revealed that student-academic performances were disclosed to be associated with the following factors: the instructor's teaching styles and instructional skills, the students' prior knowledge, their study habits and the cohort atmosphere, that is, implementation of the innovative tool alone might not be sufficient to significantly improve student performance. Nonetheless, the interactive, collaborative instructional approach sensed to appeal to females more than it did to males, disclosing the potential of TEAL in narrowing the learning gap between genders.

\section{Objectives of the Study}

To find out the Relationship between Social Intelligence and Achievement in Science among High School Students.

\section{Hypothesis of the Study}

There is significant means score difference in social intelligence in relation to academic achievement in science among high school students.

\section{Method}

Based on the study the Researcher has adopted Normative survey Research design, as it is intended to measure the relationship between Social Intelligence and Achievement in Science among High School students.

\section{Sample}

By using Stratified Random technique the Investigator selected 669 High School students which include 389 male and 280 female studying in Government, Aided, Private High Schools in and around Coimbatore District.

\section{Tools}

Social Intelligence Scale (SIS) By Baskaran, P.\& Anandan, K. (2011)

Achievement in Science developed by Investigator

\section{Analysis of Data}

Table 1: Mena and Standard Deviation Scores of Social Intelligence and Achievement in Science among High School Students in Total

\begin{tabular}{|l|l|l|l|l|l|}
\hline \multirow{2}{*}{ S.No } & \multirow{2}{*}{$\mathrm{N}$} & \multicolumn{2}{|l|}{ Social intelligence } & \multicolumn{2}{l|}{ Achievement in science } \\
\cline { 3 - 6 } & & Mean & $\mathrm{Sd}$ & Mena & SD \\
\hline 01. & 669 & 70.64 & 4.45 & 49.27 & 12.87 \\
\hline
\end{tabular}


From the above table 1 the result reveals that the Mean Scores of Social Intelligence and achievement in science in total are 70.64, 49.27 respectively.

Table 2: Relationship between Social Intelligence and Achievement in Science among High School Students in Total

\begin{tabular}{|l|l|l|}
\hline Category & $\mathbf{N}$ & 'r' Value \\
\hline Social intelligence and achievement in science & 669 & $0.23 * *$ \\
\hline
\end{tabular}

** Correlation is significant at the 0.01 level (2-tailed)

From the above table 4 it is seen that the 'r' value, 0.23 at 0.01 level. It is understood from the result that there is a significant relationship between social intelligence and achievement in science among High School Students.

Table 3: Significant Relationship between Social Intelligence and Achievement in Science among High School Students at High, Moderate and Low Level of Achievement

\begin{tabular}{|l|l|l|l|l|l|l|}
\hline \multirow{2}{*}{ Category } & \multicolumn{2}{|l|}{ Achievement } \\
\cline { 2 - 7 } & $\mathbf{N}$ & High & N & Moderate & N & Low \\
\hline $\begin{array}{l}\text { Social intelligence } \\
\text { and achievement in } \\
\text { science }\end{array}$ & 170 & $0.34 * *$ & 285 & $0.17 * *$ & 214 & $0.35^{* *}$ \\
\hline
\end{tabular}

** Correlation is significant at the 0.01 level (2-tailed)

It is obviously seen from the above table 3 reveals that the ' $r$ ' values 0.34 are significant at the 0.01 level. It is understood from the result that there is significant relationship between social intelligence and achievement in science among high school students at high and low level of achievement. At the same time there is significant relationship between social intelligence and achievement in science among high school students at moderate level of achievement.

\section{Discussion of the Study}

The aim of the present study is to find out the Social Intelligence and Achievement in Science among High School students. From the Descriptive Analysis, it is understood that the Mean Scores of Social Intelligence in Total is 70.64, and Achievement is 49.27. It implies that there is difference in mean scores Social Intelligence and Academic Achievement among High School students.

\section{Conclusion of the Study}

The result shows that there is mean score difference of Social Intelligence and Academic Achievement in Science among High School students. Similarly there is significant relationship between Social Intelligence and Academic Achievement in science among High School students. 


\section{References}

[1] Bloom, Benjamin, S. et. al. (1956). Taxonomy of Educational Objectives Handbook - I, Cognitive Domain, New York, David McKay Co., Inc.,

[2] Buch, M.B.(1987). Third Survey of Research in Education (1978-1983) National Council for Education Research Training, New Delhi.

[3] Ebenezer, J.A. and Leo Stanly, S. (2009). Adjustment and Achievement in Physics of XI Standard students, Unpublished Thesis, Madurai Kamaraj University.

[4] Golden, S. A. R. (2011). Problems and Prospectus of Distance Learning. Bharathidhasan University, 343, 344.

[5] Golden, S. A. R. (2011). Strategy For Success Of Human Beings:-Time Management.

[6] Golden, S. A. R. (2016). RURAL STUDENTS' ATTITUDE TOWARDS ENGLISH AS MEDIUM OF INSTRUCTION IN HIGHER EDUCATION - AN ANALYSIS. International Journal of Research, 3(Special Issue - 16), 1-10.

[7] Regi, S. B., \& Golden, S. A. R. (2014). A Study On Educational Loan Availed By Students In Trichy City. JOURNAL OF INTERNATIONAL ACADEMIC RESEARCH FOR MULTIDISCIPLINARY (JIARM), 2(1).

[8] Sutton, C. Words (1992). Science and Learning, B.Uckingham, Open University Press.

[9] Vaidya, Narendra (1999). Science Teaching in Schools for the 21st Century, Deep and Deep Publications, New Delhi.

[10] Vijaya Sundari, K. (1996). Scientific Temper in relation to obedience among Higher Secondary Students, Unpublished Thesis, Madurai Kamaraj University. 